\title{
EKSPLORASI EKSTRAK ETANOL BEBERAPA TUMBUHAN BERPOTENSI SEBAGAI ANTIKETOMBE
}

\section{EXPLORATION OF SOME POTENTIAL ETHANOLIC PLANT EXTRACT AS ANTIDANDRUFF AGENT}

\author{
Ernanin Dyah Wijayanti* ${ }^{*}$ dan Endang Susilowati ${ }^{1}$ \\ ${ }^{1}$ Akademi Farmasi Putra Indonesia Malang \\ Jl. Barito 5 Malang \\ *E-mail: nanin.wijayanti@gmail.com
}

\section{Histori Artikel:}

Submitted:

$05 / 08 / 2017$

Revised:

$12 / 08 / 2017$

Accepted:

$19 / 09 / 2017$

\begin{abstract}
ABSTRAK
Ketombe merupakan salah satu masalah rambut yang disebabkan oleh fungi Malassezia furfur sehingga untuk pengendaliannya diperlukan agen antifungi. Beberapa tumbuhan telah digunakan secara empiris untuk terapi antiketombe antara lain: inggu (Ruta angustifolia), bambu tali (Gigantochloa apus), johar (Senna siamea), jintan hitam (Nigella sativa), apukat (Persea americana), dadap serep (Erythrina lithosprema), nagasari (Palaquium rostratum), pisang (Musa paradisiaca), sidaguri (Sida rhombifolia), tomat (Solanum lycopersicum), kethuk (Alocasia macrorrhiza) dan komak (Dolichos lablab). Penelitian ini bertujuan untuk membuktikan aktivitas antifungi ekstrak etanol tumbuhan uji dan menentukan nilai Kadar Hambat Minimum (KHM) dan Kadar Bunuh Minimumnya (KBM). Masing-masing simplisia tumbuhan uji diekstraksi dengan metode maserasi menggunakan pelarut etanol $70 \%$ selama 5 hari. Pengujian aktivitas antifungi terhadap Malassezia furfur menggunakan metode difusi sumuran, yang dilanjutkan dengan penentuan KHM dan KBM dengan metode dilusi. Hasil penelitian menunjukkan bahwa semua ekstrak etanol tumbuhan uji memiliki aktivitas antifungi yang bervariasi terhadap Malassezia furfur. Aktivitas yang kuat ditunjukkan oleh ekstrak etanol kulit buah pisang, daun bambu tali, daun komak, biji jintan hitam dan daun inggu. Nilai KHM masing-masing ekstrak antara lain: kulit buah pisang, daun bambu tali dan daun komak (10\%), biji jintan hitam (20\%), daun inggu (30\%), daun dadap serep dan daun johar (50\%), daun tomat (60\%), daun apukat dan daun nagasari (70\%). Ekstrak etanol daun sidaguri dan daun kethuk tidak memiliki nilai KHM. Semua ekstrak etanol tumbuhan uji tidak memiliki nilai Kadar Bunuh Minimum (KBM).
\end{abstract}

Kata kunci: antifungi, ekstrak etanol, ketombe

\begin{abstract}
Dandruff is one of hair problem caused by Malassezia furfur, which can be controlled by antifungal agents. Empirically, some plants have been used as antidandruff treatment: rue (Ruta angustifolia), bamboo tali (Gigantochloa apus), blackwood cassia (Senna siamea), black cummin (Nigella sativa), avocado (Persea americana), Indian coral tree (Erythrina lithosprema), gutta percha (Palaquium rostratum), banana (Musa paradisiaca), cuban jute (Sida rhombifolia), tomato (Solanum lycopersicum), taro (Alocasia macrorrhiza) and lablab (Dolichos lablab). This research was aimed to observe antifungal activity, Minimum Inhibitory Concentration (MIC) and Minimum Fungicidal Concentration (MFC) of these 12 potential plants against Malassezia furfur. Each of plant simplisia was extracted by immersion in $70 \%$ ethanol for 5 days. Antifungal activity assay against Malassezia furfur were conducted using agar well diffusion, followed by dilution method to determine MIC and MFC. The results showed that all of plant ethanolic extract have various antifungal activity against Malassezia
\end{abstract}


furfur. Strong activity showed by banana peels extract, bamboo tali leaves extract, lablab leaves extract, black cumin seeds extract and rue leaves extract. MIC values obtained were $10 \%$ for banana peels extract, bamboo tali and lablab leaves extract, $20 \%$ for black cumin seeds extract, $30 \%$ for rue leaves extract, $50 \%$ for Indian coral and blackwood cassia leaves extract, $60 \%$ for tomato leaves extract, $70 \%$ for avocado and gutta percha leaves extract. Whereas cuban jute and taro leaves extract did not show MIC values. All of plant ethanolic extracts did not show MFC values.

Keywords: antifungal, dandruff, ethanolic extract

\section{PENDAHULUAN}

Ketombe merupakan salah satu permasalahan rambut yang memperoleh banyak perhatian dalam bidang kosmetika. Ketombe menjadi masalah yang sangat umum dikeluhkan oleh masyarakat. Leger (2005) dalam Turner et al. (2012) menyatakan bahwa setengah dari populasi dunia akan menderita kondisi tersebut pada suatu waktu.

Perkembangan ketombe disebabkan oleh 3 faktor utama, antara lain kolonisasi Malassezia, produksi sebum dan kondisi individu. Gupta (2004) dalam Kumar (2013) menyatakan bahwa Malassezia furfur adalah fungi (dikenal sebagai Pityrosporum) yang termasuk dalam genus Malassezia, yang bertanggung jawab pada terjadinya beberapa penyakit kulit termasuk ketombe pada rambut.

Untuk mengendalikan pertumbuhan Malassezia dibutuhkan agen antifungi. Bahan tersebut umumnya digunakan dalam produk perawatan untuk ketombe, antara lain zinc pyrithione, asam salisilat, derivate imidazole asam glikolat, steroid, sulfur dan derivate tar. Namun penggunaan bahan-bahan tersebut terbatas karena masalah keamanan dan adanya keluhan konsumen serta sebagian besar tidak mencegah infeksi kembali. Selain itu, kosmetik rambut yang sintetik menyebabkan berbagai efek samping misalnya toksisitas terhadap mata, rambut menjadi terlalu kering dan deposit garam pada helai rambut (Agarwal et al., 2009; Halith et al., 2009 dalam Naveen et al., 2012).

Alternatif yang dapat digunakan untuk terapi ketombe adalah menggunakan tumbuhan obat. Beberapa tumbuhan secara empiris telah digunakan untuk mengatasi ketombe, antara lain inggu (Ruta angustifolia), bambu tali (Gigantochloa apus), johar (Senna siamea), jintan hitam (Nigella sativa), apukat (Persea americana), dadap serep (Erythrina subumbrans), nagasari (Palaquium rostratum), pisang (Musa paradisiaca), sidaguri (Sida rhombifolia), tomat (Solanum lycopersicum), kethuk (Alocasia macrorrhiza) dan komak (Dolichos lablab). Tumbuhan-tumbuhan tersebut diduga mengandung senyawa antifungi sehingga mampu mengendalikan pertumbuhan ketombe, namun belum ada data penelitian yang membuktikan adanya aktivitas antifungi terhadap Malassezia furfur atau fungi penyebab ketombe. Oleh karena itu, penelitian ini dilakukan dengan tujuan untuk membuktikan aktivitas antifungi ekstrak etanol tumbuhan uji dan menentukan nilai Kadar Hambat Minimum (KHM) dan Kadar Bunuh Minimumnya (KBM). Fungi indikator yang digunakan adalah Malassezia furfur. Penelitian ini diharapkan dapat memberikan data yang lengkap mengenai aktivitas antifungi, sehingga dapat memberikan informasi mengenai potensi tumbuhan tersebut sebagai antiketombe.

\section{METODE PENELITIAN}

Penelitian ini tergolong penelitian deskriptif dengan replikasi sebanyak 3 kali. Variabel penelitian meliputi aktivitas antifungi, nilai Kadar Hambat Minimum dan Kadar Bunuh Minimum terhadap Malassezia furfur. Bahan utama penelitian meliputi Malassezia furfur, daun inggu, daun bambu tali, daun komak, daun johar, daun kethuk, daun apukat, daun tomat, daun sidaguri, daun nagasari, daun dadap serep, kulit pisang, biji jintan hitam, ethanol $70 \%$ dan media Saboraud's Dextrose Agar. Alat yang digunakan antara lain glassware, bejana maserasi, pengayak No 25, evaporator, corong Buchner, autoklaf, inkubator, spektrofotometer, jangka sorong, cork borer.

\section{A. Ekstraksi Tumbuhan Uji}

Sebanyak 100 gram simplisia ditambahkan dengan $1000 \mathrm{ml}$ etanol 70\%, kemudian dilakukan maserasi selama 5 × 24 jam sambil sesekali diaduk. Setelah $5 \times 24$ jam disaring kemudian filtrat dievaporasi untuk mendapatkan ekstrak kental.

\section{B. Skrining Fitokimia}

(1) Uji Alkaloid: Sampel dibasakan denagn Ammonia $10 \%$ ditambahkan CHCL3 lalu digerus dan dikocok. Lapisan CHCL3 diambil lalu ditambahkan HCL $1 \mathrm{~N}$ dan di kocok. 
Diambil fasa airnya lalu dibagi 3 pada masingmasing bagian ditambahkan: Pereaksi Dragendrof, Meyer, Bouchardat; (2) Uji Flavonoid: Sampel dipanaskan dengan campuran logam magnesium dan asam klorida $2 \%$, kemudian disaring; (3) Uji Kuinon: Sampel dikocok dengan air panas lalu dididihkan selama 5 menit, lalu disaring kedalam filtrat dan ditambahkan $\mathrm{NaOH} 1 \%$; (4) Uji Tanin dan Polifenol: Sampel ditambahkan air panas dan dididihkan selama 5 menit, setelah dingin disaring, fitratnya di bagi 2 masing-masing: ditambahkan FeCL3 1\% dan Gelatin 10 \%; (5) Uji Saponin: Sampel ditambah air panas dan dididihkan selama 5 menit, setelah dingin disaring. Fitratnya diambil sebanyak $10 \mathrm{ml}$ lalu dikocok selama 10 detik.

\section{Uji Aktivitas Antifungi}

Biakan Malassezia furfur disuspensikan menggunakan Saboraud's dextrose broth kemudian diukur \%T hingga diperoleh nilai 25. Suspensi fungi diinokulasikan pada cawan petri sebanyak $1 \mathrm{ml}$, kemudian dituang media Saboraud's dextrose agar dan dibiarkan hingga memadat. Media selanjutnya dilubangi menggunakan cork borer berukuran $9 \mathrm{~mm}$ kemudian dimasukkan ekstrak ke dalam sumuran tersebut. Inkubasi dilakukan selama 24-48 jam pada suhu $37^{\circ} \mathrm{C}$, kemudian diamati dan diukur zona hambat yang terbentuk.

\section{Penentuan Kadar Hambat Minimum dan Kadar Hambat Maksimum}

Ekstrak etanol tumbuhan uji yang memiliki aktivitas antifungi diencerkan hingga konsentrasi tertentu (100\% sampai $0 \%$ ). Biakan Malassezia furfur diinokulasikan pada media Sabouraud's dextrose broth, kemudian ditambah dengan ekstrak tumbuhan uji dengan konsentrasi yang berbeda-beda. Inkubasi dilakukan pada suhu $30^{\circ} \mathrm{C}$ selama 24 jam, selanjutnya diamati kekeruhan pada masing-masing tabung uji. Nilai Kadar Hambat Minimum ditunjukkan oleh berkurangnya kekeruhan pada tabung uji. Tabung dengan kekeruhan yang rendah atau tampak jernih, diinokulasikan pada media Sabouraud's dextrose agar dan diinkubasi pada $30^{\circ} \mathrm{C}$ selama 3 hari, selanjutnya diamati ada tidaknya koloni Malassezia furfur yang tumbuh. Tidak adanya koloni pada media menunjukkan nilai kadar bunuh minimum.

\section{HASIL DAN PEMBAHASAN}

Eksplorasi ekstrak etanol dari beberapa tumbuhan yang berpotensi sebagai antiketombe dilakukan sebagai salah satu upaya pembuktian resep empiris yang digunakan oleh masyarakat tertentu. Diketahui terdapat 12 tumbuhan yang telah digunakan sebagai terapi antiketombe secara empiris antara lain inggu, bambu tali, johar, jintan hitam, apukat, dadap serep, nagasari, pisang, sidaguri, tomat, kethuk dan komak. Secara umum, penggunaan tumbuhan tersebut adalah dengan menumbuk bagian tumbuhan kemudian dioleskan pada kulit kepala dan dibiarkan beberapa saat.

Masing-masing bahan tanaman diuji skrining fitokimia sebelum diuji aktivitasnya. Hasil pengujian dapat dilihat pada Tabel 1

Tabel 1. Hasil Uji Skrining Fitokimia

\begin{tabular}{clccccc}
\hline No & \multicolumn{1}{c}{ Sampel } & Alkaloid & Flavonoid & Kuinon & Saponin & Tanin \\
\hline 1 & Daun apukat & + & + & + & - & + \\
2 & Daun bambu tali & - & + & - & + & - \\
3 & Daun dadap serep & + & + & - & + & + \\
4 & Daun inggu & + & + & + & + & + \\
5 & Biji jintan hitam & + & - & + & + & + \\
6 & Daun johar & + & + & + & + & + \\
7 & Daun komak & - & + & + & + & + \\
8 & Daun nagasari & + & + & + & + & + \\
9 & Kulit buah pisang & + & + & + & - & + \\
10 & Daun sidaguri & - & + & + & - & + \\
11 & Daun kethuk & - & + & + & - & - \\
12 & Daun tomat & + & - & + & + & - \\
\hline
\end{tabular}

Berdasarkan hasil skrining fitokimia dapat diketahui bahwa sebagian besar simplisia mengandung flavonoid, alkaloid, kuinon, saponin dan tanin, dimana hal tersebut sesuai dengan informasi yang diperoleh dari penelitian sebelumnya. Daun apukat mengandung saponin, tanin, flavonoid, terpenoid (Ogundare and Oladejo, 2014), daun 
bambu tali mengandung derivat fenol, hidrokarbon siklik dan aromatik, asam lemak dan ester, keton rantai panjang, alkohol rantai panjang, senyawa mengandung nitrogen (Mulyono et al., 2013), daun dadap serep mengandung saponin, flavonoid, polifenol, alkaloid, daun inggu mengandung asam amino, saponin, alkaloid, flavonoid, kumarin, tanin, minyak atsiri, glikosida, sterol, triterpen (Hnatyszyn et al., 1974; Chen et al., 2001 dalam Haddouchi et al., 2013), biji jintan hitam mengandung minyak atsiri, kalsium, protein, karbohidrat, serat, saponin (Raval et al., 2010), daun johar mengandung saponin, tanin, resin, steroid (Bukar et al., 2009), daun kethuk mengandung flavonoid, kolesterol, asam amino, glikosida, alkaloid (Mubeen et al., 2012), daun komak mengandung sterol, asam lemak, palmitat, palmitoleat, linoleat dan linolenat, alkaloid, trigonelin (Nasrin et al., 2012), kulit buah pisang mengandung tanin, flobatanin, flavonoid, glikosida, terpenoid, alkaloid (Ighodaro, 2012), daun sidaguri mengandung alkaloid, n-alkan, alkohol rantai panjang, sterol (Prakash et al., 1981; Goyal and Rani, 1989 dalam Logeswari et al., 2013), daun tomat mengandung alkaloid, steroid, flavonoid (Amid et al., 2011), seskuiterpen dan alkohol (Huang et al., 2012; Inoue, 2002 dalam Kobayashi et al., 2012).

Semua tumbuhan uji yang digunakan pada penelitian ini mengandung senyawa yang berkhasiat sebagai antifungi, minimal satu jenis senyawa. Berdasarkan hal tersebut, maka semua tumbuhan uji memiliki potensi untuk digunakan sebagai kandidat antiketombe. Arif et al., (2009) menyatakan bahwa golongan utama senyawa tumbuhan yang memiliki sifat antifungi antara lain fenol, flavonoid, kumarin, kuinon, saponin, xanthon, alkaloid, lektin dan polipeptida serta terpenoid dan minyak atsiri.

Hasil pengujian aktivitas antifungi menunjukkan bahwa semua ekstrak etanol tumbuhan uji memiliki aktivitas antifungi terhadap Malassezia furfur. Diameter zona bening yang dihasilkan bervariasi, beberapa menunjukkan diameter zona bening yang besar dan beberapa menunjukkan diameter zona bening yang kecil. Diameter zona bening terbesar ditunjukkan oleh ekstrak etanol kulit buah pisang dengan nilai rata-rata $65,6 \mathrm{~mm}$, sedangkan zona bening terkecil ditunjukkan oleh ekstrak etanol daun kethuk dengan nilai rata-rata $2,3 \mathrm{~mm}$.

Tabel 2. Hasil Pengujian Aktivitas Antifungi

\begin{tabular}{clccc}
\hline No. & Ekstrak Etanol & $\begin{array}{c}\text { Rerata Diameter } \\
\text { Zona Bening (mm) }\end{array}$ & KHM (\%) & KBM (\%) \\
\hline 1 & Daun apukat & 9,5 & 70 & - \\
2 & Daun bambu tali & 64,3 & 10 & - \\
3 & Daun dadap serep & 18 & 50 & - \\
4 & Daun inggu & 21 & 30 & - \\
5 & Biji jintan hitam & 60 & 20 & - \\
6 & Daun johar & 18 & 50 & - \\
7 & Daun komak & 65 & 10 & - \\
8 & Daun nagasari & 7,5 & 70 & - \\
9 & Kulit buah pisang & 65,6 & 10 & - \\
10 & Daun sidaguri & 3,3 & - & - \\
11 & Daun kethuk & 2,3 & - & - \\
12 & Daun tomat & 11,2 & 60 & - \\
\hline
\end{tabular}

Berdasarkan data tersebut, aktivitas antifungi dari ekstrak etanol tumbuhan uji dapat dikategorikan menjadi kuat, sedang dan lemah. Upadhyay (2014) menyatakan bahwa, antimikroba tergolong lemah apabila diameter zona hambat kurang dari $7 \mathrm{~mm}$, tergolong sedang apabila lebih dari $12 \mathrm{~mm}$ dan tergolong kuat apabila lebih dari $18 \mathrm{~mm}$. Berdasarkan katergori tersebut, maka ekstrak etanol tumbuhan uji yang tergolong memiliki aktivitas antifungi yang kuat antara lain daun bambu tali, daun inggu, biji jintan hitam, daun komak dan kulit buah pisang. Sedangkan ekstrak etanol tumbuhan uji yang tergolong memiliki aktivitas antifungi yang sedang antara lain daun dadap serep dan daun johar. Ekstrak etanol lainnya yaitu daun apukat, daun nagasari, daun sidaguri, daun kethuk dan daun tomat tergolong memiliki aktivitas antifungi yang lemah.

Hasil penentuan KHM dan KBM juga dapat dilihat pada Tabel 2. Nilai KHM menunjukkan konsentrasi ekstrak etanol terendah yang mampu menghambat pertumbuhan Malassezia furfur, sedangkan nilai KBM menunjukkan kadar terendah yang mampu membunuh fungi uji. 
KHM/MIC didefinisikan sebagai konsentrasi minimal suatu bahan yang menghambat pertumbuhan mikroorganisme. KHM memungkinkan kuantifikasi sensitivitas strain fungi tertentu terdapap agen antifungi. KHM pada umumnya ditentukan baik menggunakan metode makrodilusi maupun mikrodilusi. Metode mikrodilusi paling banyak digunakan melalui teknik pengenceran 2 kali yang standar. Penentuan KBM/MFC juga diperlukan untuk mengetahui aktivitas fungisidal. KBM dapat ditentukan melalui peningkatan konsentrasi KHM (Murray et al., 1999 dan Balows et al., 1991 dalam Vila et al., 2013).

Hasil penelitian yang diperoleh menunjukkan bahwa ekstrak etanol daun bambu tali, ekstrak etanol daun komak serta ekstrak etanol kulit buah pisang memiliki nilai KHM paling rendah, dimana pada konsentrasi $10 \%$ telah mampu menghambat pertumbuhan fungi uji. Apabila dikorelasikan dengan hasil pengujian aktivitas antifungi, ketiga ekstrak tersebut juga menunjukkan diameter zona bening yang paling besar. Selain ketiga ekstrak tersebut, ekstrak etanol biji jintan hitam dan daun inggu juga memiliki nilai KHM yang cukup rendah yaitu $20 \%$ dan $30 \%$. Sedangkan ekstrak etanol lainnya menunjukkan nilai KHM yang cukup besar, antara lain ekstrak etanol daun dadap serep dan daun johar sebesar 50\%, ekstrak etanol daun tomat sebesar 60\%, ekstrak etanol daun apukat dan daun nagasari sebesar 70\%. Ekstrak etanol daun sidaguri dan daun kethuk tidak memiliki nilai KHM dimana tingkat kekeruhan pada tabung uji tidak berkurang pada konsentrasi ekstrak tertinggi.

Hasil penentuan KBM menunjukkan bahwa semua ekstrak etanol tumbuhan uji tidak memiliki nilai KBM. Hal ini ditunjukkan oleh masih adanya pertumbuhan fungi uji pada konsentrasi $100 \%$. Berdasarkan hal tersebut, maka ekstrak etanol tumbuhan uji yang digunakan tergolong bersifat fungistatik.

Pada dasarnya semua tumbuhan uji yang digunakan mengandung senyawa bioaktif yang berpotensi sebagai antifungi dan dapat digunakan sebagai kandidat antiketombe. Apabila dikorelasikan dengan hasil uji fitokimia, diketahui bahwa tumbuhan uji yang digunakan mengandung senyawa-senyawa antifungi seperti alkaloid, flavonoid, tanin dan polifenol, saponin serta kuinon. Selain senyawa-senyawa tersebut, beberapa tumbuhan uji diketahui mengandung minyak atsiri yang juga memiliki peranan dalam aktivitas antifungi. Biji jintan hitam, daun inggu, daun apukat dan daun tomat diketahui mengandung minyak atsiri sehingga menimbulkan bau yang khas pada tumbuhan tersebut.

Senyawa-senyawa antifungi yang terkandung dalam tumbuhan uji memiliki mekanisme antifungi yang bermacam-macam. Senyawa golongan fenolik seperti flavonoid, tanin dan polifenol, memiliki mekanisme aksi antifungi melalui gangguan pada membran sel, disfungsi mitokondria, penghambatan pembentukan dinding sel dan penghambatan pembelahan sel. Flavonoid mampu mengganggu homeostasis mitokondria tanpa menyebabkan peningkatan level ROS intraseluler dan tidak melibatkan apoptosis. Flavonoid juga menunjukkan kemampuan mengganggu integritas membran sel fungi namun model aksinya belum jelas. Sedangkan mekanisme antifungi polifenol terjadi melalui penahanan proses sklus sel pada fase S. Hal ini menunjukkan bahwa polifenol mampu menghambat pembelahan sel sehingga mempengaruhi pertumbuhan sel fungi. Polifenol pada tumbuhan lain menunjukkan mekasnisme disfungsi mitokondria sehingga menyebabkan akumulasi ROS, serta penghambatan sintesis kitin pada dinding sel (Davidson and Taylor, 2007; Kang et. al., 2010; Pinto et al., 2009; Smith et al., 2008; Wu et al., 2009; Wu et al., 2008 dalam Freiesleben and Jager, 2014).

Senyawa saponin beraksi sebagai antifungi melalui mekasisme penggangguan membran sel. Saponin beraksi langsung pada biomembran dan beraksi seperti deterjen. Saponin bergabung dengan bagian lipofilik pada membran bilayer setelah membentuk kompleks dengan kolesterol dan bagian hidrofilik di luar sel. Karena pembentukan kompleks dengan kolesterol, maka saponin tidak spesifik untuk fungi, namun dapat mempengaruhi sel mamalia (Morrissey and Osbourn, 1999; Agostini-Costa et al., 2012; Hostettmann and Marston, 1995; Cho et al., 2013; Keukens et al., 1992; Keukens et al., 1995; Ashour and Wink, 2011 dalam Freiesleben and Jager, 2014).

Senyawa alkaloid beraksi sebagai antifungi melalui mekasisme penggangguan membran sel. Mekanisme tersebut terjadi melalui penghambatan biosintesis ergosterol atau pembentukan kompleks dengan ergosterol (Arneson and Durbin, 1968; Bagiu et al., 2012 dalam Freiesleben and Jager, 2014).

Senyawa kuinon memiliki mekanisme aksi antifungi melalui penghambatan pembentukan dinding sel, disfungsi mitokondria, penghambatan sintesis RNA-DNA-protein serta 
penghambatan efflux pump. Naftokuinon beraksi melalui gangguan terhadap dinding sel fungi, transkripsi mRNA dan sintesis protein. Sedangkan antrakuinon beraksi melalui depolarisasi membran potensial mitokondria dan penghambatan efflux pump. Senyawa yang mampu menghambat efflux pump memiliki potensi untuk digunakan dalam kombinasi dengan obat antifungi yang lain untuk mencegah resistensi obat (Kang et al., 2010; Van Der Weerden et al., 2010 dalam Freiesleben and Jager, 2014).

Minyak atsiri menujukkan aktivitas antifungi melalui perusakan membran sel. Minyak atsiri termasuk golongan lipofilik sehingga mampu masuk melalui dinding sel dan membran sitoplasma fungi kemudian mengganggu struktur komposisi membran. Oleh karena itu minyak atsiri menyebabkan membran fungi semakin permeabel. Studi lain melaporkan bahwa kemampuan minyak atsiri dalam merusak membran sel secara langsung disebabkan oleh adanya komponen terpenoid yang bersifat lipofilik (Bakkali et al., 2008; Jung et al., 2007 dalam Freiesleben and Jager, 2014).

Meskipun semua tumbuhan uji mengandung senyawa antifungi, namun hasil yang diperoleh bervariasi mulai dari aktivitas antifungi yang kuat, sedang maupun lemah. Mekanisme antifungi yang berbeda dapat memberikan pengaruh pada besar kecilnya aktivitas antifungi. Selain itu tidak semua senyawa mampu tersari secara maksimal dengan metode maserasi menggunakan etanol $70 \%$. Ekstrak etanol yang di dalamnya mengandung senyawa antifungi dalam kadar yang tinggi dapat memberikan aktivitas antifungi yang besar. Sebaliknya, apabila ekstrak etanol yang di dalamnya mengandung senyawa antifungi dengan kadar yang rendah maka akan memberikan aktivitas antifungi yang kecil.

\section{KESIMPULAN}

Semua ekstrak etanol tumbuhan uji yang digunakan memiliki aktivitas antifungi yang bervariasi terhadap Malassezia furfur. Aktivitas yang kuat ditunjukkan oleh ekstrak etanol kulit buah pisang, daun bambu tali, daun komak, biji jintan hitam dan daun inggu.

Nilai Kadar Hambat Minimum (KHM) secara berurutan mulai dari yang terendah antara lain ekstrak etanol kulit buah pisang, daun bambu tali dan daun komak sebesar $10 \%$, ekstrak etanol biji jintan hitam sebesar 20\%, ekstrak etanol daun inggu sebesar 30\%, ekstrak etanol daun dadap serep dan daun johar sebesar 50\%, ekstrak etanol daun tomat sebesar $60 \%$, ekstrak etanol daun apukat dan daun nagasari sebesar 70\%. Ekstrak etanol daun sidaguri dan daun kethuk tidak memiliki nilai KHM. Semua ekstrak etanol tumbuhan uji tidak memiliki nilai Kadar Bunuh Minimum (KBM). Perlu dilakukan pengembangan metode ekstraksi menggunakan variasi pelarut yang sesuai sehingga mampu menyari senyawa antifungi dalam tumbuhan uji secara maksimal.

\section{DAFTAR PUSTAKA}

Amid, A., S. Semail, P. Jamal. (2011). Tomato Leaves Methanol Extract Possesses Antiinflamatory Activity via Inhibition of Lipopolysacharide (LPS)-Induced Prostaglandin (PGE2). African Journal of Biotechnology Vol. 10 (81): 18674-18678

Arif, T., J. D. Bhosale, N. Kumar, T. K. Mandal, R. S. Bendre, G. S. Lavekar, R. Dabur. (2009). Natural Products-Antifungal Agents Derived from Plants. Journal of Asian Natural Products Research Vol. 11 No. 7: 621-638

Bukar, A., Mukhtar, M.D. and Hassan, A.S. (2009). Phytochemical Screening and Antibacterial Activity of Leaf Extracts of Senna siamea (Lam) on Pseudomonas aeruginosa. Bayero Journal of Pure and Applied Sciences, 2(1):139 - 142

Chhavi, S., D. Sushma, A. Mohammad. (2011). Potential of Herbal As Antidandruff Agents. International Journal Research of Pharmacy. Vol 2 (3): 16-18

Dhuhita, A. (2008). Aktivitas Minyak Atsiri Rimpang Bengle (Zingiber cassumunar roxb.) terhadap Pertumbuhan Malassezia furfur In Vitro. Artikel Karya Tuis Ilmiah. Universitas Diponegoro. Semarang

Freiesleben, S.H and A.K. Jager. (2014). Correlation between Plant Secondary Metabolites and Their Antifungal Mechanisms-A Review. Medicinal and Aromatic Plants Vol. 3 (2)

Haddouchi, F., T.M. Chaouche, Y. Zaouali, R. Ksouri, A. Attou, A. Benmansour. (2013). Chemical Composition and Antimicrobial Activity of The Essential Oils from Four Ruta Species Growing in Algeria. Food Chemistry 141: 253-258

Kobayashi, F., K. Ishida, H. Ikeura, S. Odake, Y. Hayata. (2012). Application of Tomato (Solanum lycopersicum) Leaf Volatiles as Antifungal Agents against Plant Pathogenis Fungi. Journal of Agricultural Sciences Vol. 4 No. 8: 231-235

Kumar, S. (2013). Analysis on the Natural Remedies to Cure Dandruff/Skin Diseasecausing Fungus-Malassezia furfur. 
Advanced Bio Tech. ISSN: 2319-6750 Vol. 12 Issue 07: 01-05

Logeswari, P., V. Dineshkumar, S.M. Prathap Kumar, and P.T.A. Usha. (2013). In-Vivo Antiinflammatory Effect of Aqueous and Ethanolic Extract of Sida rhombifolia L. Root. International Journal of Pharmaceutical Science and Research Vol. 4(1): 316-321

Mita, S. R., D. Rusmiati, S. A. F. Kusuma. (2009). Pengembangan Ekstrak Etanol Kubis (Brassica oleracea var. Capitata L.) Asal Kabupaten Bandung Barat dalam Bentuk Sampo Antiketombe terhadap Jamur Malassezia furfur. Laporan Akhir Penelitian Peneliti Muda (LITMUD) tidak diterbitkan. Bandung: Universitas Padjadjaran

Mubeen, U. S., M. Vimlesh, B. Santanu. (2012). Laxative and Diuretic Property of Ethanolic Extract of Leaves of Allocasia macrorrhiza Linn. on Experimental Albino Rats. International Research journal of Pharmacy 3 (2): 174-176

Mulyono, N., B. W. Lay, L. Ocktreya, S. Rahayu. (2013). Antidiarrheal Activity of Apus Bamboo (Gigantochloa apus) Leaf Extract and Its Bioactive Compounds. American Journal of Microbiology 4 (1): 1-8

Nasrin, F., I.J. Bulbul, Y. Begum, S. Khanum. (2012). In Vitro Antimicrobial and Cytotoxicity Screening of n-Hexane, Chloroform and Ethyl Acetate Extracts of Lablab purpureus (L.) Leaves. Agriculture and Biology Journal of North America 3 (2): 43-48

Naveen S, Karthika S, Sentila R, Mahenthiran R, Michael A. (2012). In-vitro evaluation of herbal and chemical agents in the management of dandruff. J. Microbiol. Biotech. Res., Vol. 2 (6): 916-921

Nirmala Nithya R, Shanmathi S, Rohini M, Sekar Babu Hariram, Arumugam $P$ and Sindhu S. (2013). Exploring the Anti- dandruff Potential of Selected Medicinal Plants. Research Journal of Pharmaceutical, Biological and Chemical Sciences Volume 4 Issue 3: 392-396

Novitasari. (2010). Efektivitas Ekstrak Kunyit (Curcuma domestica) dibandingkan Dengan Ketokenazol 2\% terhadap Pertumbuhan Malassezia sp. pada Ketombe. Semarang : Fakultas Kedokteran Universitas Diponegoro

Ogundare A.O., Oladejo B.O. (2014). Antibacterial Activities of Leaf and Bark Extract of Persea americana. American Journal of Ethnomedicine 1 (1): 064-071

Pooja, A., N. Arun, K. Maninder. (2013). Screening Of Plant Essential Oils For Antifungal Activity Against Malassezia Furfur. International Journal of Pharmacy and Pharmaceutical Sciences Vol 5, Issue 2: 37-39

Raval, B.P., T.G. Shah, M.P. Suthar, A. L. Ganure. (2010). Screening of Nigella sativa Seeds for Antifungal Activity. Annals of Biological Research 1 (1): 164-171

Turner, G. A., M. Hoptroff, C. R. Harding. (2012). Stratum Corneum Dysfunction in Dandruff. International Journal of Cosmetic Science Vol 34 (4): 298-306

Upadhyay, R.K. (2014). Evaluation of Antibacterial and Antifungal Activities of Olive (Olea europea) Essential Oil. International Journal Green Pharmacy Vol 8 (3): 180-186

Vila, R., B. Freixa, S. Chanigueral. (2013). Antifungal Compounds from Plants. Recent Advances in Pharmaceutical Sciences III: 23-43 ISBN: 978-81-7895-605-3

Vyjayanthi, G., C. Kulkarni, A. Abraham, S.A. Kolhapure. (2004). Evaluation of AntiDandruff Activity And Safety Of Polyherbal Hair Oil: An Open Pilot Clinical Trial. The Antiseptic 101(9), 368-372 